ISSN (Online) 2710-3315

https://doi.org/ 10.20535/EHS.2021.232878

УдК 620.9; 662.939.9

\title{
ДОСЛІДЖЕННЯ ПРОЦЕСУ СУМІСНОГО СПАЛЮВАННЯ ПРИРОДНОГО ГАЗУ 3 RDF В МОДЕЛЬНІЙ КАМЕРІ ЗГОРЯННЯ
}

\author{
С. Г. Кобзар, О. І. Топал, Л. С. Гапонич, І. Л. Голенко \\ Інститут вугільних енерготехнологій НАН Украӥни \\ вул. Андріївська, 19, Київ, 04070, Україна \\ e-mail:dr.topal@gmail.com
}

За офіційною статистикою в Україні у 2020 р. обсяг збирання твердих побутових відходів (ТПВ) становив понад 54,1 млн. м³, або понад 15,4 млн. тонн, які захоронюються на 6 тис. сміттєзвалищ і полігонів загальною площею майже 9 тис. га. У 2020 р. в Україні перероблено і утилізовано лише 4,2\% ТПВ, з них 1,2\% спалено, а 3,0\% потрапило на заготівельні пункти вторинної сировини та сміттєпереробні установки. Захоронення майже 95\% необроблених ТПВ на полігонах призводить до щорічної втрати значної кількості енергоресурсів та цінних матеріалів, які містяться у відходах. За нашими розрахунками теплота згоряння ТПВ становить для міст України 4,8-7,0 МДж/кг, вона подібна до теплоти згоряння торфу та бурого вугілля [1].

Сортування ТПВ не вирішує завдання повної утилізації відходів, а їх відокремлена частина, що містить органічну складову, має використовуватись для виробництва електричної та теплової енергії в екологічно безпечний спосіб. ТПВ мають значний енергетичний потенціал, який можна використати шляхом вилучення з них вторинного палива, щорічний обсяг якого в Україні може сягати близько 2,5-3,5 млн т з теплотою згоряння в межах 10-25 МДж/кг. Отже, розробка та впровадження екологічно безпечних методів утилізації ТПВ та альтернативних палив на їх основі, зокрема RDF (refuse derived fuel), $є$ актуальною проблемою, вирішення якої потребує системного та науково-обгрунтованого підходу. Водночас, термічна утилізація відходів, яка відбувається без урахування особливостей морфологічного та елементного складу ТПВ, може призводити до утворення вкрай небезпечних для людини сполук - діоксинів та фуранів. Для запобігання небезпечному спалюванню ТПВ в СС існують жорсткі директиви (2010/75/СС , 2000/76/СС та інші [1-3]) щодо режимних параметрів нових теплових установок, які утилізують ТПВ та палива на їх основі. Вітчизняні нормативні документи, що розробляються, також сприяють поступовому витісненню спалювання несортованого ТПВ, замінюючи його або спалюванням палива 3 TПВ - RDF гарантованої якості, або іншими технологіями термохімічної переробки [1]. Мета роботи полягала у дослідженні процесу спільного спалювання палива з ТПВ з природним газом та оцінці впливу заміщення частини природного газу RDF/SRF на експлуатаційні та екологічні характеристики процесу спалювання.

Для дослідження вибрано інтегрований в циліндричну камеру згоряння газомазутний пальник ГМП-16 [4]. Стандартний пальник ГМП-16 оснащено отвором для мазутної форсунки. Отвір для мазутної форсунки розташований на осі пальника та має діаметр 48 мм. Організація подачі RDF в пальник потребує окремого розгляду та технічних рішень. Паливо, 
що подається, має бути належним чином подрібненим та дрібнодисперсним.

Всі розрахунки було проведено для теплової потужності пальника 18,6 МВт. Надлишок повітря для всіх випадків становив $\alpha=1,05$; температура природного газу та повітря $-20{ }^{\circ} \mathrm{C}$; температура стінок камери згоряння $-300^{\circ} \mathrm{C}$. При теплоті згоряння $\mathrm{CH}_{4}$ 50,1 МДж/кг витрата газу становить 0,371 кг/с, витрата повітря при надлишку 1,05-6,72 кг/с. В модельній камері згоряння повітря подавалося з закрученням, моделювався аксіально-лопатковий завихрювач 3 лопатками, встановленими під кутом $45^{\circ}$. RDF подавалося разом 3 димовими газами $з$ вмістом кисню $2 \%$ (за масою) зі швидкістю $20 \mathrm{~m} / \mathrm{c}$ при температурі $100{ }^{\circ} \mathrm{C}$. Приймалося, що тверде паливо має наступний розподіл діаметрів частинок по фракціям: 50; 100; 150; 200 мкм, а кожна фракція частинок містить $25 \%$ маси.

Математична модель. Усереднені за числом Re рівняння Нав’є-Стокса вирішувалися для в'язкого теплопровідного газу в стаціонарній постановці 3 використанням в якості моделі теплообміну повного рівняння збереження енергії. Для замкнення рівняння руху використовувалася $R N G k-\varepsilon$ модель турбулентності. Густина суміші газів розраховувалася за допомогою закону ідеального газу для суміші газів. Вплив гравітації враховувався шляхом завдання сили земного тяжіння в напрямку протилежному направленню осі Ү. Радіаційний теплообмін моделювався за допомогою моделі Дискретного Переносу (Discrete Transfer).

Для моделювання горіння природного газу зроблені наступні припущення:

1. Природний газ складається тільки з метану.

2. Горіння метану відбувається за двостадійним механізмом (реакцій 1,2 ):

$$
\begin{gathered}
\mathrm{CH}_{4}+1 / 2 \mathrm{O}_{2}=\mathrm{CO}+2 \mathrm{H}_{2}, \\
\mathrm{CO}+1 / 2 \mathrm{O}_{2}=\mathrm{CO}_{2} .
\end{gathered}
$$

Для розрахунку процесу горіння застосована гібридна схема. Середня швидкість хімічної реакції компоненти визначалася як мінімальне значення швидкості реакції визначене за моделлю дисипації вихорів $\left(R_{E D C}\right)$ [5] та закону Ареніуса $\left(R_{A r}\right)$ [6]:

$$
R=-\min \left(R_{E D C}, R_{A r}\right),
$$

де швидкість реакції за законом Ареніуса:

$$
R_{A r}=A T^{b} \exp \left(-\frac{E_{a}}{R T}\right)[\text { Fuel }]^{c}[\text { Oxid }]^{d}[\text { Product }]^{e}
$$

Значення коефіцієнтів в формулі (4) наведені у табл. $1[5,6]$.

Значення коефіціснтів

Таблиця 1.

\begin{tabular}{|c|c|c|c|c|c|c|}
\hline Реакція & $A$ & $b$ & $c$ & $d$ & $e$ & $\begin{array}{c}E_{a,} \\
\text { ккал/моль }\end{array}$ \\
\hline$(1)$ & $1,5 \cdot 10^{7}, 1 / \mathrm{c}$ & 0 & $-0,3$ & 1,3 & 0 & 30 \\
$(2)$ & $10^{14,6}$, моль $^{-0,75} \mathrm{~cm}^{2,25} \mathrm{c}^{-1}$ & 0 & 1 & 0,25 & {$\left[\mathrm{H}_{2} \mathrm{O}\right]^{0,5}$} & 40 \\
$(7)$ & $8,3 \cdot 10^{6} \times \mathrm{M}_{\mathrm{CH} 4} / \mathrm{M}_{\text {Fuel GAS }}$ & 0 & $-0,3$ & 1,3 & & 30 \\
\hline
\end{tabular}

Швидкість реакції за моделлю дисипації вихорів Магнусена [5], визначалася за формулою:

$$
R_{E D C}=A_{E D C} \frac{\varepsilon}{k} \rho \cdot \min \left\{\bar{Y}_{\text {fuel, } \left., \frac{\bar{Y}_{o x}}{s}, B_{E D C} \frac{1}{1+s} \bar{Y}_{\text {prod }}\right\}}\right\}^{\prime}
$$

де $\bar{Y}$ fuel, $\bar{Y}$ ox - масова концентрація палива та окислювача, $s$ - стехіометричне відношення реакції паливо/окислювач; $A_{E D C}$ и $B_{E D C}$ константи моделі. В моделі дисипації вихорів 
використовувалися стандартні значення констант $A_{E D C}=4$ и $B_{E D C}=0,5$.

В дослідженні використовувався склад ТПВ, який характерний для великих міст. В табл. 2 наведено масові частки складових ТПВ, які використовувалися для створення RDF [7].

Таблиця 2.

\section{Фізико-хімічні характеристики складових TПВ та отриманого RDF}

\begin{tabular}{|l|c|c|c|c|c|c|c|c|c|}
\hline \multirow{2}{*}{ Складова } & \multirow{2}{*}{$\begin{array}{l}\text { Масова } \\
\text { частка, \% }\end{array}$} & \multicolumn{4}{|c|}{ Технічний аналіз, \% } & \multicolumn{3}{|c|}{ Елементний склад , \% } \\
\cline { 3 - 12 } & $\mathrm{W}^{\mathrm{r}}, \%$ & $\mathrm{~A}^{\mathrm{r}}, \%$ & $\mathrm{~V}^{\mathrm{r}}, \%$ & $\begin{array}{l}\mathrm{Q}^{\mathrm{r}}, \\
\mathrm{MДж/ \kappa г}\end{array}$ & $\mathrm{C}^{\text {daf }}$ & $\mathrm{H}^{\text {daf }}$ & $\mathrm{N}^{\text {daf }}$ & $\mathrm{O}^{\text {daf }}$ \\
\hline Поліетилен & 22,0 & 1,05 & 1,04 & 97,91 & 37,73 & 78,93 & 12,03 & 0,07 & 8,98 \\
\hline Пластмаса & 24,0 & 0,95 & 5,09 & 93,96 & 37,80 & 80,42 & 12,86 & 0,22 & 6,50 \\
\hline Папір, картон & 19,0 & 25,68 & 10,68 & 53,19 & 10,78 & 45,72 & 6,74 & 0,24 & 47,30 \\
\hline Текстиль & 8,0 & 6,26 & 10,99 & 73,18 & 20,61 & 64,96 & 7,47 & 1,39 & 26,18 \\
\hline $\begin{array}{l}\text { Дрібні волок- } \\
\text { на поліетиле- } \\
\text { ну, пластмаси }\end{array}$ & 27,0 & 28,48 & 17,51 & 42,55 & 10,22 & 60,48 & 8,30 & 1,47 & 29,75 \\
\hline RDF & 100,0 & 13,53 & 9,09 & 71,54 & 23,83 & 66,88 & 9,85 & 0,62 & 22,65 \\
\hline
\end{tabular}

Для моделювання горіння частинок твердого палива використовувалася вбудована в пакет Fluent стандартна модель. Згідно цієї моделі транспорт частинок моделювався шляхом розв'язання рівняння руху частинки в постановці Лагранжа. Зміну розміру діаметру частинки твердого палива прийнято пропорційною зміні її зовнішньої поверхні чи масі (у разі, коли частинка вважається непроникною для газів реагентів).

При потраплянні частинки твердого палива в модельну камеру згоряння 3 нею відбуваються наступні процеси: сушка; термічна деструкція; горіння вуглецю. В дослідженні було прийнято, що процес термічної деструкції твердого палива починається після досягнення температури виходу летких $T_{\text {devol }}=550 \mathrm{~K}$. Передбачалося, що RDF при цьому розкладається на коксовий залишок (CHAR) та леткі (Fuel GAS): RDF $\rightarrow$ CHAR + Fuel GAS.

Зміна маси частинки залежить від матеріалу твердого палива, залишку летких у матеріалі та задовольняє закону Арреніуса з властивими конкретному матеріалу значеннями енергії активації $E_{v o l}$ та передекспонентним фактором $k_{v o l 0}$ :

$$
k_{v o l}=k_{v o l 0} \exp \left(-\frac{E_{v o l}}{R T_{p}}\right) .
$$

Кінетичні параметри у виразі (6) були взяті відповідно до рекомендацій роботи [7], де для $\mathrm{RDF}$ відповідного складу (див. табл. 2) були запропоновані наступні значення $E_{v o l}=$ 106,5 кДж/моль та $k_{\text {vol0 }}=2,47 \times 10^{6} 1 / \mathrm{c}$.

Для моделювання гетерогенного горіння коксового залишку використовувалася стандартна дифузійно-кінетична модель горіння вуглецю. Прийнято, що горіння відбувається на зовнішній поверхні за сумарною (брутто) реакцією $\mathrm{C}+\mathrm{O}_{2}=\mathrm{CO}_{2}$.

Після виходу летких їх горіння відбувається у гомогенному середовищі. Приймається, що 
леткі мають властивості метану. Горіння відбувається за одностадійним механізмом:

$$
\text { Fuel GAS }+\mathrm{O}_{2} \rightarrow \mathrm{CO}_{2}+\mathrm{H}_{2} \mathrm{O}
$$

Середня швидкість хімічної реакції летких визначалася як мінімальне значення швидкості реакції визначене за моделлю дисипації вихорів та закону Ареніуса згідно виразам (3) - (5). В моделі дисипації вихорів використовувалися стандартні значення констант $A_{E D C}=4$ и $B_{E D C}=0,5$, а для залежності (4) використовувалися кінетичні параметри для одностадійного механізму горіння метану відповідно до [6,9]. Для розрахунку емісії оксидів азоту в атмосферу при спалюванні вугілля використовувалися термічний, prompt та паливний механізми утворення оксидів азоту.

Результати дослідження. На рис. 1-7 наведені результати комп'ютерного моделювання спільного процесу спалювання у модельній камері [4] природного газу та дрібнодисперсних частинок RDF у кількості, що становить 10\% вхідної потужності суміші (по теплу). На рис. 13 наведено концентрацію вуглецю в частинках RDF, зміну часу руху частинок по траєкторії вздовж камери згоряння та концентрацію летких.

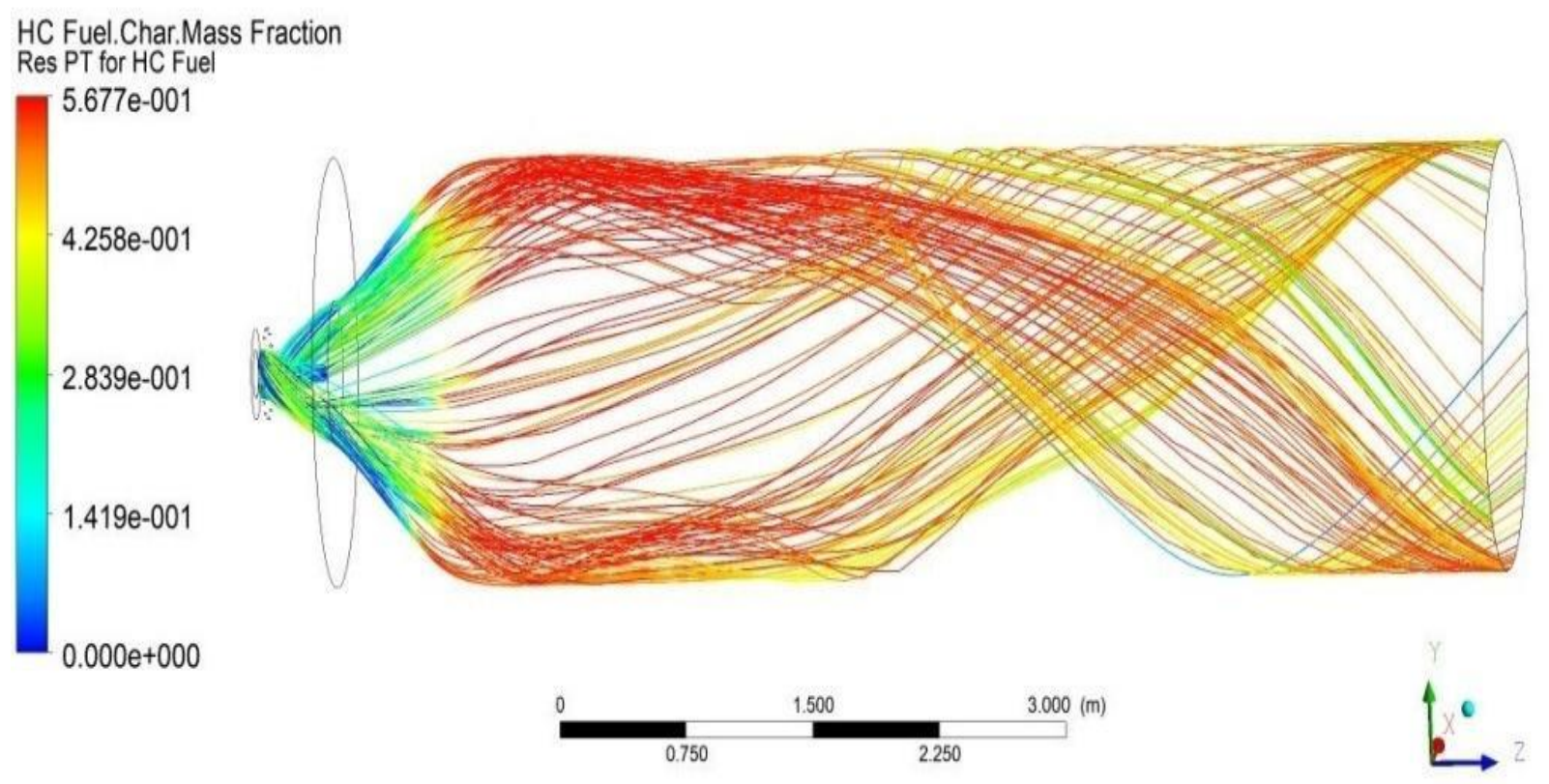

Рисунок 1. Концентрація коксового залишку в частинках твердої фази

Аналіз отриманих результатів показує, що вихід летких відбувається в межах пальникового пристрою, після чого, під дією відцентрових сил частинки палива, які на цей момент переважно складаються з вуглецю та золи, відносяться до периферії камери згоряння та рухаються в граничному шарі, який характеризується низькими значеннями концентрацій кисню та температурою, що потребує більшого часу перебування для повного згоряння вуглецю. Це пов'язано в першу чергу з використанням сильного завихрення, що характерно для стандартного пальника ГМП-16, який розрахований на спалювання газоподібного та 
рідкого палив.

HC Fuel.Particle Traveling Time

Res PT for HC Fuel

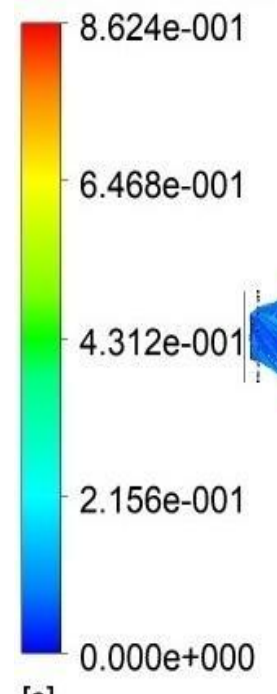

[s]
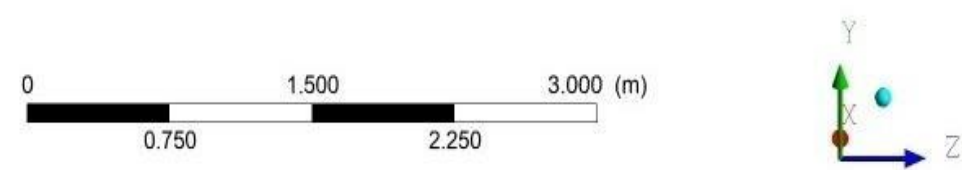

Рисунок 2. Тривалість перебування частинок твердого палива в камері згорання

\section{Fuel Gas.Mass Fraction}

Plane 1

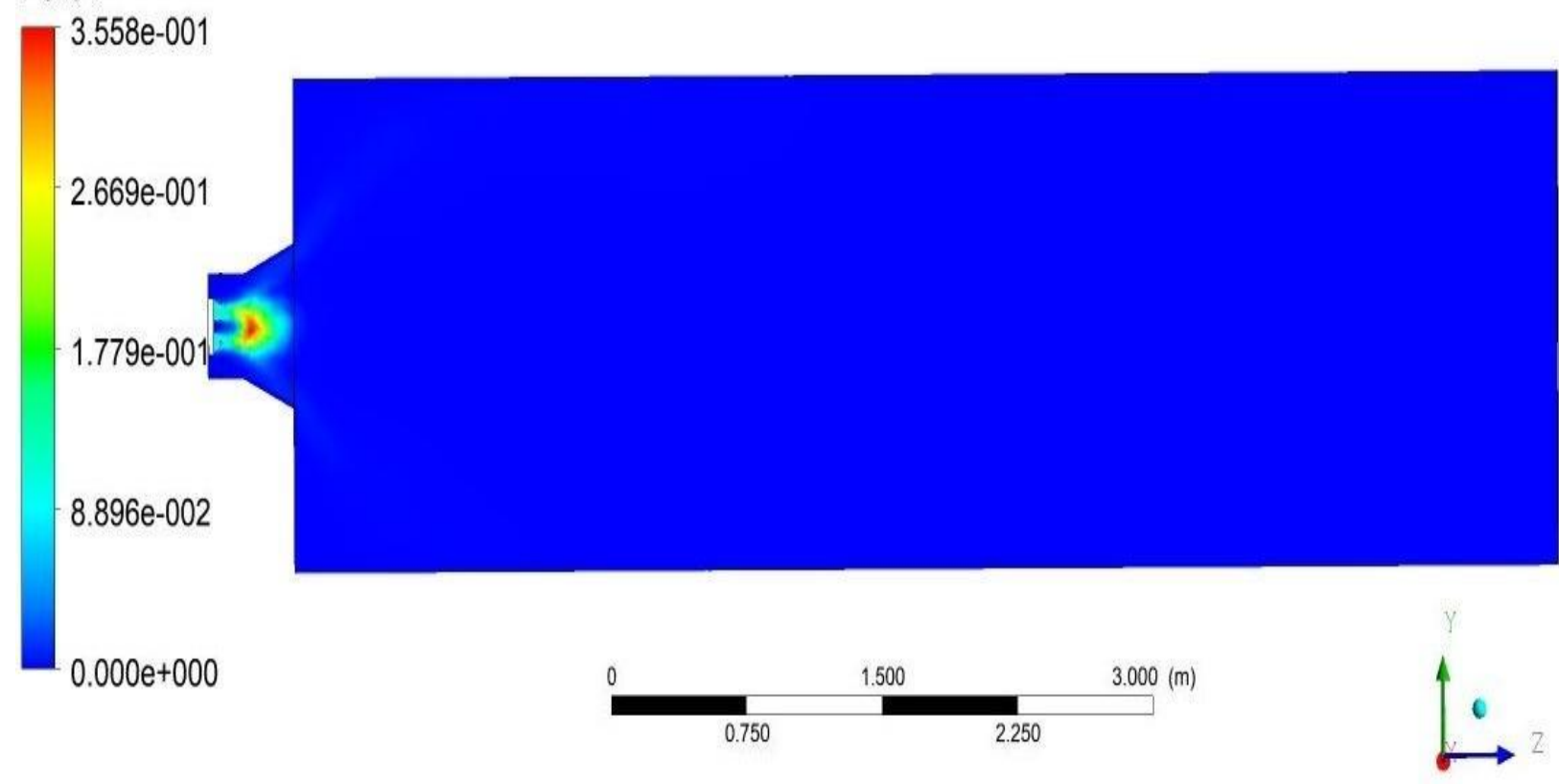

Рисунок 3. Концентрація летких

На рис. 4 показано поле осьової швидкості, що викликається аксіально-лопатковим завихрювачем. Зона зворотних токів, що утворюється на вісі камери дозволяє добре спалювати 
газоподібне паливо, що підтверджується розподілом концентрації оксиду вуглецю (дивись рис. 5).
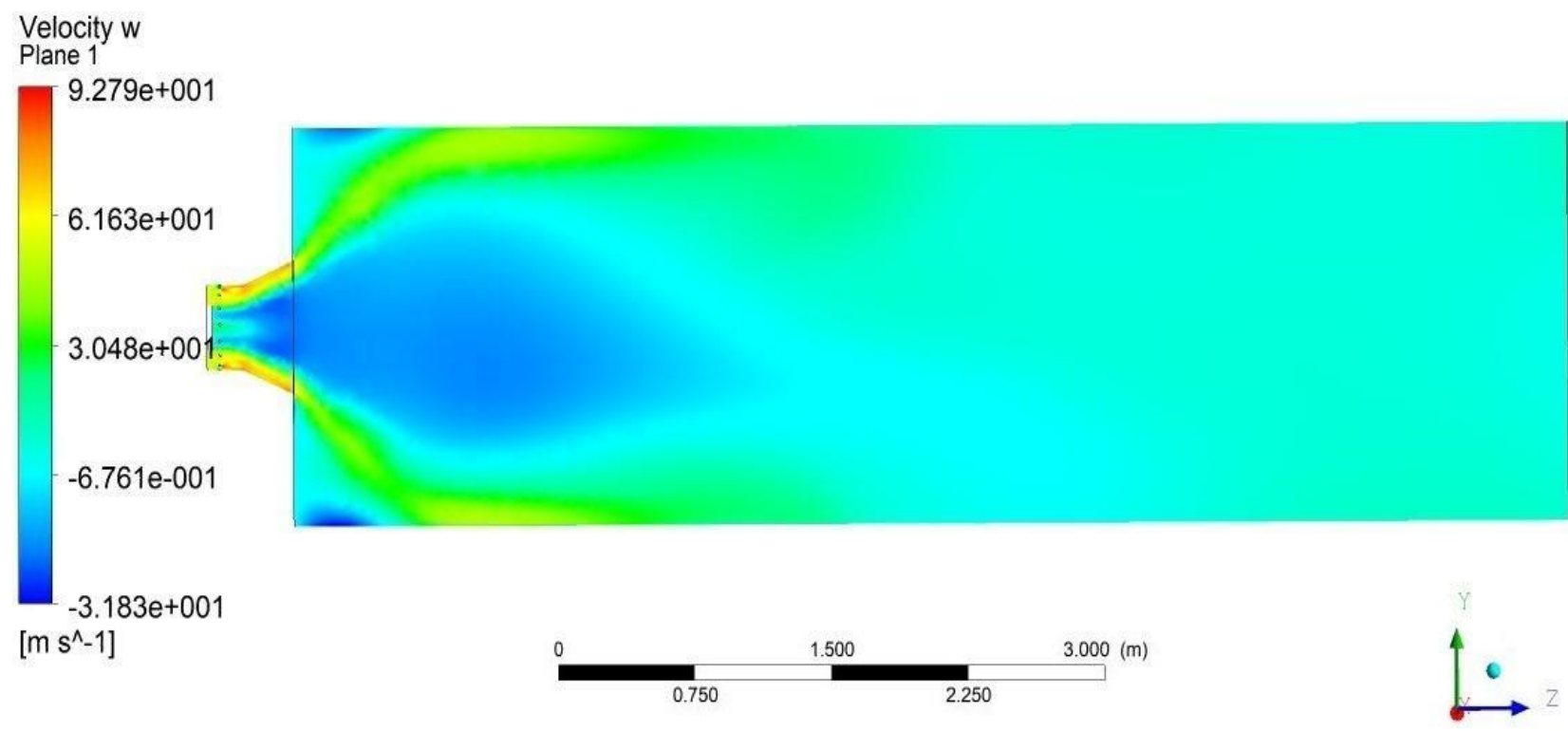

Рисунок 4. Розподіл осьової швидкості

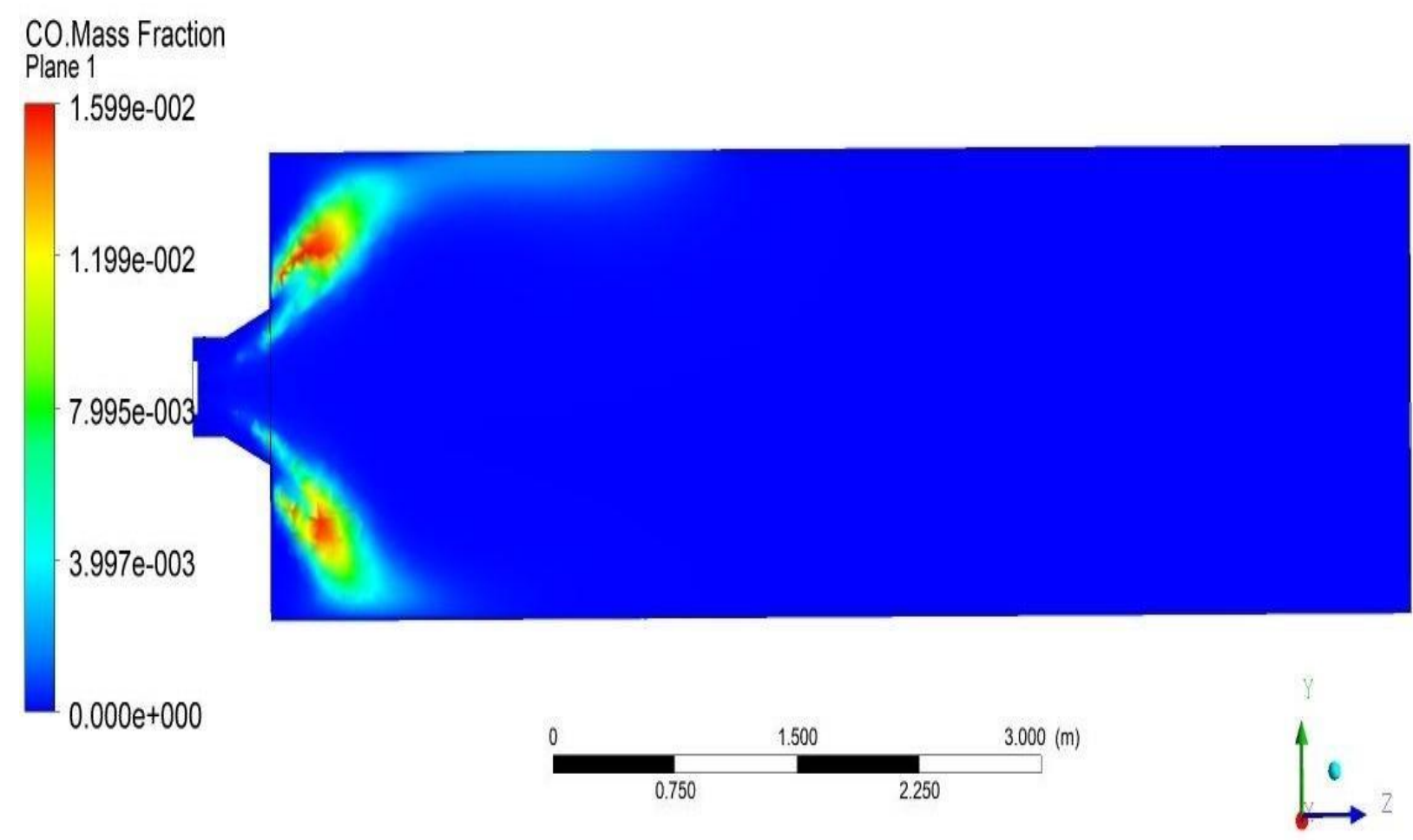

Рисунок 5. Розподіл концентрації оксиду вуглецю

При спалюванні RDF з характеристиками, наведеними в табл. 2, внаслідок високої концентрації летких в твердому паливі та швидкого їх виділення значно зменшується розмір частинок. Це призводить до збільшення відносної густини частинок та зменшення їх лобового 
опору. Сукупність зазначених факторів призводить до відтиснення частинок на периферію камери згоряння.

На рис. 6 показано температурне поле на вісі камери згоряння. Характер температурного поля обумовлений особливостями гідродинаміки, що описані вище. На рис. 7 показано розподіл концентрації оксидів азоту в центральному перерізі камери згоряння. Зони підвищеної генерації NOx, що розташовані на бокових поверхнях камери згоряння можна пояснити паливним механізмом утворення оксидів азоту.

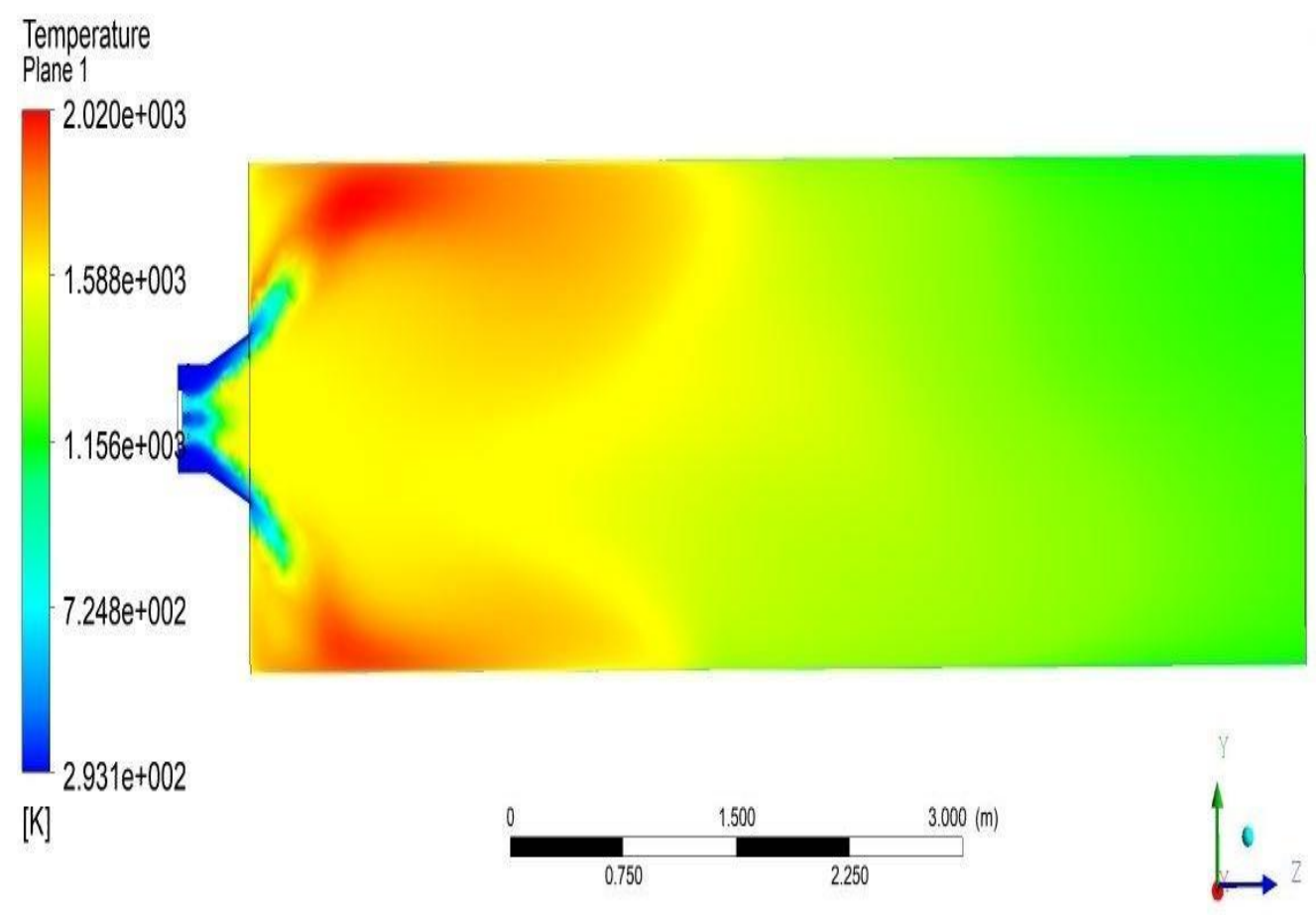

NO.Mass Fraction

Рисунок 6. Розподіл температури

Plane 1

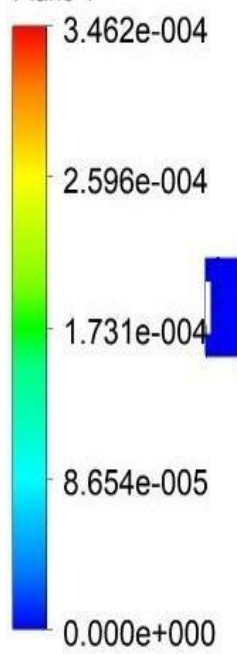

$0.000 \mathrm{e}+000$
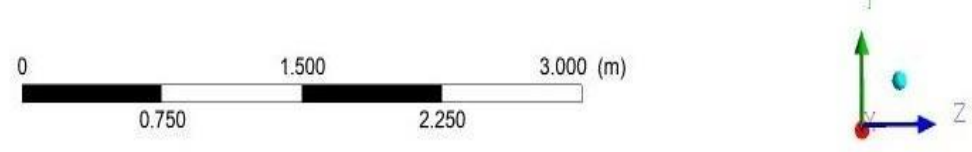

Рисунок 7. Концентрація оксидів азоту 
Як видно з рис. 3, вихід летких відбувається в межах пальникового пристрою та амбразури. Далі частинки RDF під дією відцентрових сил відносяться на периферію потоку де відбувається утворення оксидів азоту за паливним механізмом. Перша зона підвищеної концентрації NOx, що знаходиться знизу розрахункової зони обумовлена сумарною дією відцентрових та гравітаційних сил, під дією яких частинки з більшою масою попадають у цю зону. В табл. 3 наведено інтегральні техніко-екологічні характеристики процесу сумісного спалювання RDF з метаном в залежності від їх теплової частки Q. Результати отримано для вихідного перетину камери згоряння.

Таблиця 3.

Інтегральні характеристики модельної камери згоряння при сумісному спалюванні метану та RDF в камері згоряння

\begin{tabular}{|l|l|l|l|l|l|l|}
\hline $\begin{array}{l}\text { Q } \\
\text { газу, \% }\end{array}$ & $\begin{array}{l}\text { QRDF, } \\
\%\end{array}$ & $\begin{array}{l}\text { Емісія CO, } \\
\text { мкг/с }\end{array}$ & $\begin{array}{l}\text { Емісія } \\
\text { вуглецю, г/с }\end{array}$ & $\begin{array}{l}\text { Втрати } \\
\text { палива, \% }\end{array}$ & $\begin{array}{l}\mathrm{T}_{\max }, \mathrm{K} \\
\text { Емісія NOх, } \\
\text { мкг/с }\end{array}$ \\
\hline 100 & 0 & 2,459 & $\sim 0$ & $\sim 0$ & 2011 & 109 \\
90 & 10 & 2,29 & 4,43 & 0,781 & 2020 & 844 \\
80 & 20 & 2,294 & 7,11 & 1,25 & 1993 & 843 \\
70 & 30 & 2,30 & 8,83 & 1,56 & 1907 & 1198 \\
\hline
\end{tabular}

Розрахунки показують, що збільшення частки RDF в складі паливної суміші призводить до зростання емісії NOx та зниженню ККД, обумовленого зростанням втрат палива. Втрати палива розраховувалися як сума втрат теплової енергії разом з вуглецем, що не згорів, та оксидом вуглецю, які залишили розрахункову область разом з продуктами згоряння. Для підвищення часу перебування частинок твердого палива необхідно провести зміни у стандартному пальнику ГПМ-16.

\section{Висновки:}

1. На цей час в Україні поступово набуває актуальності та потребує відповідного науково обгрунтованого вирішення проблема поводження із відходами різних видів, зокрема ТПВ, щорічна кількість яких сягає великих значень - близько 11-12 млн т. ТПВ мають значний енергетичний потенціал, який можна використати шляхом вилучення з них вторинного палива у вигляді RDF, щорічний обсяг якого в Україні може сягати близько 2,5-3,5 млн т з теплотою згоряння в межах 10-25 МДж/кг.

2. Одним із шляхів термічної утилізації RDF $є$ їх спалювання, у тому числі спільне із природним газом, з додержанням жорстких екологічних вимог (Директива ЕС 2010/75 тощо) 3 метою виробництва теплової та електричної енергії (зокрема у існуючих котлах малої та середньої паропродуктивності за умов їх модернізації).

3. Визначено вплив додавання RDF на процес їх спільного спалювання із природним газом для заданої геометрії елементу камери згоряння. Отримано розрахункові залежності 
температур, швидкостей, розподілу концентрацій газових компонентів, залишку вуглецю у твердій фазі, концентрації оксидів азоту та монооксиду вуглецю у камері згоряння. За попередніми оцінками визначено можливість додавання частки RDF у кількості до 20\% (за теплом по входу) під час їх спільного з природним газом спалювання, що не змінить суттєвим чином техніко-екологічні показники роботи камери згоряння.

\section{Література:}

1. Гапонич Л. С., Голенко І. Л., Топал А. І. Нормативне регулювання, сучасний стан поводження та перспективи енергетичного використання твердих побутових відходів в Україні // Проблеми агальної енергетики, 2019, 3(58), с. 45-54. URL: DOI: https://doi.org/10.15407/pge2019.03.

2. Neuwahl F., Cusano G., Benavides J. G., Holbrook S., Roudier S. Best Available Techniques (BAT) Reference Document for Waste Incineration, 2019, 764 p.; EUR 29971 EN; DOI:10.2760/761437.

3. Directive 2008/98/EC of the European Parliament and of the Council of 19 November 2008 on waste and repealing certain Directives. Official Journal of the European Union. 22.11.2008. L 312. P. 3-30. URL: http://data.europa.eu/eli/dir/2008/98/oj.

4. Кобзар С. Г., Топал О.І., Гапонич Л.С., Голенко І.Л., Моделювання процесу сумісного спалювання природного газу з паливами із твердих побутових відходів // Електронне моделювання, 2020, Т. 42, №6, с. 74-92. URL: https://doi.org/10.15407/emodel.42.06.072.

5. Magnussen B. F., Hjertager B. W. On the structure of turbulence and a general is ededdy dissipati on concept for chemical reaction in turbulent flow//19th AIAA Aerospace Meeting, 1981, USA: St. Louis.

6. Westbrook C. K., Dryer F. L. Simplified Reaction Mechanisms for the Oxidation of Hydrocarbon Fuels in Flames // Combustion Science and Technology, 1981, Vol. 27, pp. 31-43.

7. Liedann B. et al. An approach to model the thermal conversion and flight behaviour of refuse derived fuel // Fuel, 2017, Vol. 200, pp. 252-271. https://doi.org/10.1016/j.fuel.2017.03.069.

8. Weber R, Kupka T, Zajac K. Jet flames of a refuse derived fuel // Combust Flame, 2009, 156, pp. 922-927. http://dx.doi.org/10.1016/j.combustflame.2008.12.011.

9. Bartok W., Sarofim A. F. et al. Fossil Fuel Combustion: A Source Book. NY: JohnWiley\&Sons, 1991, 866 p. 